\title{
Masora Biblii hebrajskiej - wprowadzenie w tematykę
}

\author{
Massoruh siag letorah \\ „Masora jest ogrodzeniem Pisma Świętego" \\ (powiedzenie żydowskie)
}

Student Biblii, który zapoznał się już z podstawami języka hebrajskiego i otwiera najbardziej popularne krytyczne wydanie Biblii hebrajskiej Biblia Hebraica Stuttgartensia (BHS) ${ }^{1}$, staje przed nie lada wyzwaniem. Oto oprócz tekstu pisanego obcym alfabetem i naszpikowanego znakami diakrytycznymi - samogłoskami i akcentami spowalniającymi czytanie - widzi na marginesach system znaków otaczających hebrajski tekst, których nie rozumie. Sporo czasu poświęcił na naukę liter i samogłosek języka hebrajskiego, a i tak po otwarciu Biblii dostrzega w tekście spółgłoskowym i dokoła niego niezrozumiałe noty i oznaczenia. System tych oznaczeń znany jest jako masora².

Zaciekawionemu studentowi sprawy nie ułatwia wstęp do BHS, który - dostępny tylko po łacinie i w językach obcych - zakłada już znajomość tematyki masory. Prolegomena do BHS zawierają listę najczęściej używanych terminów masory małej, ale lista jest niekompletna, a definicje podane tylko w języku łacińskim. Nie umieszczono żadnych przykładów

${ }^{1}$ Biblia Hebraica Stuttgartensia. Editio funditus renovata, ed. K. Elliger et W. Rudolph, masoram curavit G. E. Weil, Stuttgart ${ }^{1} 1967-1977 ;{ }^{2} 1984 ;{ }^{4} 1990 ;$ K. Elliger, W. Rudolph, A. Schenker ${ }^{5} 1997$. To wydanie krytyczne Biblia Hebraica, oparte na Kodeksie Leningradzkim, jest tekstem standardowym dla studiów akademickich.

${ }^{2} \mathrm{Na}$ marginesie dolnym oprócz oznaczeń dla masory znajduje się aparat krytyczny, jednak jest on czytelny, skróty są dobrze objaśnione w BHS, zatem sprawia znacznie mniej trudności niż system not masoreckich. 
zastosowania masory, a użyte definicje mogą być dla studenta - i najczęściej są - niejasne i niezrozumiałe.

Jeśli student będzie zdeterminowany, nie podda się i zacznie szukać opracowań na temat masory w języku polskim, znów czeka go rozczarowanie. Zarówno w polskiej literaturze biblijnej,jaki na polskojęzycznych stronach internetowych znaleźć można jedynie podstawowe i niepełne informacje na ten temat. Brak obszerniejszego niż definicja opracowania, brak zestawienia i objaśnienia znaków masory (słowniczka), nie mówiąc już o całościowym tłumaczeniu i wykładzie not masoreckich. O masorze i pracy masoretów wspominają gramatyki języka hebrajskiego, jednak nie znajdziemy szerszej dyskusji na jej temat czy instrukcji, jak masorę czytać. Z drugiej strony duża część obcojęzycznej literatury technicznej na temat masory - głównie w specjalistycznych czasopismach naukowych - najczęściej zakłada już znajomość techniki jej odczytywania. Do niedawna wyczerpujące wprowadzenia i studia nad masorą można było spotkać jedynie w języku hebrajskim³ ${ }^{3}$.

Warto więc powiedzieć parę słów o tym, czym jest masora. Sam fakt pieczołowitego umieszczenia pełnej masory w krytycznym wydaniu Biblii, którym posługuje się świat tłumaczy i egzegetów chrześcijańskich (BHS), oraz jeszcze większej pieczołowitości przy jej nanoszeniu w najnowszym piątym wydaniu krytycznym Biblii hebrajskiej Biblia Hebraica Quinta (BHQ) ${ }^{4}$ - co edytorsko jest sprawą bardzo trudną - świadczy, że w poważnych badaniach nad hebrajskim tekstem Pisma Świętego masora nie może być pominięta. To argument tylko formalny. Ważniejszy jest fakt, że system oznaczeń w i wokół tekstu biblijnego znany jako masora to istna biblioteka informacji o tekście hebrajskim na etapie jego definitywnego ustalania. Podaje takie informacje o tekście, bez

${ }^{3}$ Np. I. Yeivin, מבוא למסורה הטברנית (Mawo lamasora hatawranit), Jerusalem 1980; M. Breuer, המסורה הנלה לתורה (Hamasora hagedola letora), New York 1992 czy liczne artykuły w hebrajskojęzycznym czasopiśmie „Tarbiz. A Quarterly for Jewish Studies” wydawanym od 1930 roku.

${ }^{4}$ Biblia Hebraica Quinta, communiter ediderunt A. Schenker i in., Peabody 2004-. Nowe piąte wydanie Biblia Hebraica, podobnie jak wydania 3 i 4, również oparte jest na Kodeksie Leningradzkim, ale posiada ulepszony i rozbudowany (m.in. o manuskrypty z Qumran, tłumaczenie masory) aparat krytyczny. Praca obliczona jest na 20 tomów, które mają być opublikowane do 2015 roku; dotychczas ukazały się: General Introduction and Megilloth 2004; Ezra and Nehemiah 2006; Deuteronomy 2007; Proverbs 2009. 
których trudne, a czasem niemożliwe staje się poprawne jego odczytanie i zinterpretowanie. A zatem warto i trzeba się z nią zapoznać i przynajmniej ogólnie umieć ją wykorzystać i zastosować w studiach biblijnych.

\section{Definicja masory}

Masora (hebr. מָסiֹ masora) oznacza „przekaz”, ,tradycję" (od hebr. czasownika מָסֵ masar - „przenosić”, „przekazywać”). Jest to system opracowany przez żydowskich uczonych (masoretów) mający na celu dokładne ustalenie wymowy i wierne przekazanie hebrajskiego tekstu Biblii. System jest zbiorem znaków, not i uwag do tekstu Starego Testamentu zapisanego początkowo tylko spółgłoskami. Ze względu na przekonanie o świętości Biblii transmisja jej treści bez najmniejszej zmiany i najmniejszego skażenia była głównym celem pracy masoretów. Masora służyła kopistom i czytelnikom, aby zachować tekst niezmienionym, nienaruszonym głównie przez skodyfikowanie poprawnego odczytania oraz wynotowanie wyjątków i niespotykanych form. Noty masoreckie mają jednocześnie charakter uwag statystyczno-egzegetycznych dotyczących samego tekstu oraz charakter poprawek, uzupełnień i wykazu miejsc paralelnych, gdy chodzi o pewne specyficzne cechy tekstu. Najczęściej masora i praca masoretów kojarzona jest z uzupełnieniem hebrajskiego tekstu spółgłoskowego o samogłoski. Jednak, jak widzimy, działalność uczonych żydowskich była znacznie bardziej rozbudowana. W skład spuścizny masoretów wchodzi cała gama znaków diakrytycznych, masora mała, masora wielka i masora końcowa, a także - o czym często zapominamy - układ tekstu, graficzne jego rozplanowanie i wprowadzone podziały na paragrafy i sekcje ${ }^{5}$.

Masora umieszczana w tekście spółgłoskowym określana jest jako znaki diakrytyczne. Są to przede wszystkim samogłoski i system

${ }^{5}$ Tzw. paraszot (parsze, paragrafy) i sedarim (sekcje). Masoreci babilońscy podzielili Torę pierwotnie na 53, potem 54 parsze - jedna parsza (parasza) na każdy szabat w roku. Masoreci tyberiadzcy zaproponowali podział Tory na sekcje, tzw. sedarim (od seder - „porządek”): 154 sekcje (na 3 lata) lub 167 sekcji (na 3,5 roku). To stało się podstawą trzyletniego cyklu liturgicznego obecnego w tradycji hebrajskiej (prototyp naszego podziału na rok A, B i C). Początek seder oznaczano literą „mem”. 
akcentów, ale także oznaczenia paragrafów, typu setuma ${ }^{6}$ i petucha ${ }^{7}$. Masora na marginesie bocznym to tzw. mas or a mała (hebr. מָ מָiֹ קְִׁ masora qetanna; łac. masora parva, stąd skrót Mp), zwana też masorą marginalną (łac. masora marginalis). Masora umieszczana w manuskryptach na marginesie dolnym i górnym, a dla BHS opracowana w osobnym tomie ${ }^{8}$, to ma sor a wiel ka (hebr. מָסוֹרָה גְדּוֹלָה masora gedola, łac. masora magna, stąd skrót Mm), zwana też masorą dolną. W pewnych manuskryptach masora umieszczona została również na początku księgi lub w innych na jej końcu. Taka lista masoreckich uwag zamieszczona w porządku alfabetycznym na końcu danej księgi, danej sekcji (np. Tora) czy całego manuskryptu (kodeksu) to tzw. mas or a koń cowa (łac. masora finalis, stąd skrót Mf). Tekst hebrajski Biblii opatrzony masorą nazywamy tekstem masoreckim (TM) ${ }^{9}$.

Akcenty masoreckie spełniające trojaką funkcję: fonologiczną (akcent toniczny, rytm), syntaktyczną (interpretacja przez podział wiersza na jednostki składniowe, interpunkcja) i muzyczną (dostosowanie do melodii, pomoc w poprawnej i płynnej wymowie tekstu). To tzw. znaki kantylacji (hebr. te'amim) wskazujące na akcent wyrazowy (pierwszoczy drugorzędny), na przerwę w recytacji (akcenty rozdzielające) czy na połączenia słów (akcenty łączące). Wyróżniamy aż 30 różnych znaków kantylacji, z czego 27 jest używanych w księgach narracyjnych, a alternatywny system 21 znaków jest używany w trzech księgach poetyckich (Psalmy, Hioba i Przysłów - tzw. Ketuwim gedolim) ${ }^{10}$.

${ }^{6}$ ס סתתוּמָה s $^{e}$ tuma (,zamknięta”) - podział tekstu wskazany przez znak ס oraz lukę na co najmniej dziewięć spacji, sygnalizujący niewielką zmianę tematu.

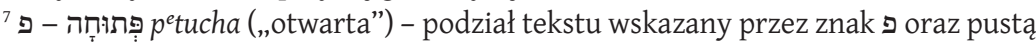
przestrzeń do końca linii, sygnalizujący zasadniczą zmianę tematu, następną parszę, która rozpoczyna się na początku kolejnej linii. Według generalnej zasady petucha wskazuje na silniejszą zmianę tematu, podczas gdy setuma na zmianę nieco subtelniejszą. Ale jak zawsze zdarzają się wyjątki.

${ }^{8}$ Massorah Gedolah iuxta codicem Leningradensem B 19a, elaboravit ediditque G. E. Weil, Romae-Stuttgartiae 1971.

${ }^{9}$ Do najlepszych opracowań masory należy wciąż ważna publikacja C. D. Ginsburga, The Massorah compiled from Manuscripts, alphabetically and lexically arranged, t. 1-4, London 1880-1905, reprint New York 1975.

${ }^{10}$ Sposoby interpretacji te'amim różnią się w poszczególnych wspólnotach żydowskich w zależności od miejsc i historycznych uwarunkowań, gdyż jak wiadomo, Żydzi 
Z kolei liczne uwagi masoreckie do hebrajskiego tekstu wynotowywane są w pierwszym rzędzie na marginesie bocznym - w masorze małej. Masora wielka ma na celu szersze objaśnienie pewnych (nie wszystkich) not masory małej, np. poprzez wynotowanie konkretnych miejsc biblijnych, szersze objaśnienie danej cechy tekstu, podanie przykładów danej formy. Masora końcowa (masora numeryczna) ma charakter uwag głównie statystycznych, podaje ilość wierszy, wyrazów i liter na końcu każdej księgi, wylicza w alfabetycznym porządku wyrazy wyróżniające się jakąś osobliwością.

Niektóre z not masoreckich - te najwcześniejsze - są hebrajskie (np. setuma, petucha), generalnie jednak językiem masoretów jest aramejski i terminy masoreckie pochodzą z języka aramejskiego.

\section{Historia powstania masory}

Przez wiele wieków tekst hebrajski funkcjonował wyłącznie w formie spółgłoskowej. Takie teksty prawie każdej księgi biblijnej odnaleziono m.in. w Qumran. W tym czasie masorę, czyli sposób odczytywania tekstu, uwagi krytyczne, statystyczne, poprawki itp. przekazywano ustnie. Żydzi notowali w pamięci wyrazy opuszczone, które jednak należy czytać, wyrazy zbędne, których czytać nie trzeba, choć są napisane, i wyrazy zmienione, które czytać należy inaczej. W miarę rozwoju studium Pisma Świętego zwracano uwagę nie tylko na ortografię i wokalizację, ale i na sposób interpretacji ksiąg świętych. Podawano więc uwagi odnoszące się do układu liter w wyrazach i ich liczbowej wartości, uwagi dotyczące wyrazów rzadko spotykanych (należało pamiętać, ile razy występują) albo tylko raz użytych w Biblii. Cały ten olbrzymi materiał przekazywany ustnie spisano między VI a X wiekiem po Chrystusie.

Najpierw pojawiła się konieczność utrwalenia wymowy słów hebrajskich przez dodanie samogłosek. System wokalizacji miał wykluczyć wieloznaczność przekazywanego tekstu spółgłoskowego Pisma Świętego ${ }^{11}$. Zadanie to podjęła żydowska szkoła w Babilonii, która opracowała system

pochodzą z różnych stron świata. Dominuje interpretacja pochodzenia aszkenazyjskiego, choć i w tej grupie mamy wiele różnic, nie mówiąc o innych grupach.

${ }^{11}$ Równocześnie zanikała umiejętność właściwej wymowy języka hebrajskiego, gdyż dawno wyszedł on z powszechnego użycia. 
wokalizacji nadspółgłoskowej (supralinearnej, łac. puncta extraordinaria), a następnie uczeni z Tyberiady, którzy wymyślili system wokalizacji podspółgłoskowej (infralinearnej, łac. litterae suspensae) ${ }^{12}$. Wykształciło się kilka środowisk uczonych żydowskich i kilka tradycji przekazu tek$\operatorname{stu}^{13}, \mathrm{z}$ których największe znaczenie miały właśnie te dwie: tradycja tyberiadzka ben Aszera (tzw. zachodni masoreci) oraz tradycja z wielkiej kolonii żydowskiej w Babilonii (babilońska, tzw. wschodni masoreci). Masora tyberiadzka ben Aszera szybko wyparła masorę babilońską (wschodnią) oraz inne systemy i od czasów Majmonidesa († 1204) stała się podstawą gramatyki hebrajskiej. Stosuje się ją powszechnie do dziś.

Talmudyczne akademie w Babilonii i Palestynie wykonały gigantyczną pracę zebrania całej dostępnej tradycji ustnej i spisanej oraz zapisania jej w postaci najbliższej oryginałowi. Celem masoretów nie była interpretacja tekstu, ale jak najwierniejsze zachowanie i przekazanie słowa Bożego. Sprawdzono każde słowo i każdą literę, wprowadzono znaki diakrytyczne dla oddania różnych odmian wymowy w językach aramejskim i hebrajskim. Uczyniono to przy pomocy punktów pisanych pod literami, oznaczając w ten sposób samogłoski długie i krótkie. Wprowadzono też różnicę w wymawianiu kilku spółgłosek, podzielono wyrazy na sylaby, zaznaczono akcenty oraz pauzy i modulację w zdaniach.

Na ogół przyjmuje się, że znaki samogłoskowe i akcentowe zostały wprowadzone jednocześnie i są częścią tego samego systemu. Jednak pewne wskazówki, zwłaszcza z systemu babilońskiego i palestyńskiego, każą przypuszczać, że akcenty były wprowadzone najpierw, przed znakami samogłoskowymi. Rzeczywiście intonacja, sposób recytacji i pauzy są trudniejsze do przekazywania i utrwalania niż samo brzmienie wyrazów z samogłoskami. Stąd wprowadzenie znaków kantylacji wydawać się mogło pilniejszą potrzebą dla przekazicieli tradycji.

Kodyfikując sposób odczytania tekstu biblijnego, masoreci pracowali bardziej całościowo. Kolejno ustalono liczbę wersów, słów i liter każdej księgi (masora numeryczna), oznaczając, które z nich mają centralne

${ }^{12}$ Zob. jak wyglądał system nadpółgłoskowy np. w: W. Tyloch, Gramatyka języka hebrajskiego, Warszawa ${ }^{2} 1985$, s. 51.

${ }^{13} \mathrm{~Np}$. tradycja palestyńska czy samarytańska, która jednak nie obejmowała całej Biblii hebrajskiej. W ramach samej masory tyberiadzkiej możemy także wyróżnić wzorzec tradycyjny i nietradycyjny, obecny w niektórych manuskryptach. 
miejsce w tekście. Wynotowano, ile razy poszczególne słowo występuje w Piśmie Świętym. Następnie dodano komentarze dotyczące brzmienia i znaczenia wyrazów, co i jak należy czytać, uwagi filologiczne i egzegetyczne (masora tekstualna). W tym celu wykorzystano na wszystkich stronach marginesy boczne do notatek, a ze względu na ograniczone miejsce komentarze zapisywano za pomocą bardzo zwięzłych skrótów. Na marginesach u góry i u dołu strony masoreci zapisywali nieco obszerniejsze komentarze dotyczące skróconych notatek z marginesów bocznych. Tekst opatrzony masorą został powszechnie uznany za autentyczny hebrajski Stary Testament i stał się podstawą tłumaczeń i dalszych opracowań.

W największym rozkwicie działalności masoretów mieli oni podzielone funkcje. Jedni przepisywali starannie tekst spółgłoskowy, dzielili go na wiersze, podając ich ilość na końcu każdej księgi; byli to tzw. soferim (pisarze, uczeni w piśmie, od hebr. sefer - „księga”). Inni nanosili samogłoski i akcenty, byli to tzw. naqdanim (punktatorzy, od hebr. nequda - „kropka”, niqud - „punktacja”), a jeszcze inni uwagi na marginesach i na końcu księgi (masoreci właściwi). Oczywiście ta sama osoba mogła wykonywać każdą z tych prac, stąd nazwy te są często traktowane zamiennie. I tak według kolofonu Kodeks Leningradzki był pracą jednego człowieka Samuela ben Jakowa, który nie tylko przepisał tekst spółgłoskowy, ale naniósł znaki diakrytyczne i całą masorę. Rodzina, która zasłynęła z wielopokoleniowej, przekazywanej z ojca na syna pracy nad tekstem biblijnym, to m.in. rodzina Ben Aszera ${ }^{14}$.

Co ciekawe, Kościół (chrześcijaństwo) praktycznie w ogóle nie zajmował się transmisją hebrajskiego tekstu Starego Testamentu. Gdy hebrajską Biblię przetłumaczono na grekę (Septuaginta, przekład

${ }^{14}$ Źródła wymieniają pięć pokoleń masoretów z tej rodziny, począwszy od Aszera Starszego żyjącego w VIII stuleciu. Jego potomkowie to Nehemiasz ben Aszer, Aszer ben Nehemiasz, Mojżesz ben Aszer i w końcu w X wieku Aaron ben Mojżesz ben Aszer. Ten ostatni masoreta z rodziny Ben Aszera opracował pierwszy zbiór zasad gramatyki hebrajskiej zatytułowany Sefer Dikdukei ha-Te'amim. 
Akwili ${ }^{15}$, Symmacha ${ }^{16}$ i Teodocjona ${ }^{17}$ ) i na łacinę (Vetus Latina), a zwłaszcza dzięki wiekopomnemu dziełu Hieronima Wulgacie - chrześcijanie pozostawili Żydom oryginalny hebrajski tekst biblijny. W Kościele szeroko korzystano z Biblii łacińskiej, a potem gdy weszły tłumaczenia na języki narodowe, dokonywano ich właśnie z Wulgaty. Praktycznie do czasów nowożytnych hebrajski tekst Biblii i jego przekaz leżał w kręgu zainteresowania Żydów.

\section{Kiedy dokładnie spisano masorę?}

Jako czas powstania właściwej wokalizacji Biblii hebrajskiej należy przyjąć lata 700-850 po Chrystusie. Najczęściej jako datę rozpoczęcia działalności masoretów wskazuje się VI, a nawet V wiek. Ale tak naprawdę bardzo mało wiemy o początkach ich działalności. Dzieje się tak z tego prostego względu, że masora - dzieło, które pozostawili po sobie żydowscy uczeni - mówi wiele o tekście hebrajskim, ale nic o samych masoretach.

Św. Hieronim żyjący na przełomie IV i V wieku wzmiankuje, że Żydzi nie mieli znaków na oznaczenie samogłosek. Talmud palestyński (koniec IV wieku) czy ważniejszy dla Żydów Talmud babiloński (V-VI wiek) świadczą o tym, że w tym okresie nie było jeszcze systemu objaśniania tekstu świętego typowego dla masoretów, choć tu zauważamy już pierwsze etapy takiego zainteresowania (np. odsyłacze do liczby wersów w księdze czy sekcji, odsyłacze do pisowni, tzw. plene i defective itp.).

Z tego względu przyjmuje się, że masoreci zaczęli działać pod koniec okresu talmudycznego. Czas, kiedy zaczęto dodawać do tekstu hebrajskiego znaki objaśniające, szacuje się na lata 600-750 po Chrystusie. 600 rok bierze się stąd, że Talmud babiloński (który ukończono właśnie okoto $600 \mathrm{roku}$ ) nie wspomina nic o systemie samogłoskowym. Natomiast data około 750 roku wynika z tego, że w drugiej połowie VIII wieku żył Aszer Starszy, którego praca nad tekstem Biblii zawierała już znaki sa-

${ }^{15}$ Zob. np. M. Abrahams, Aquila's Greek Version of the Hebrew Bible, London 1919.

${ }^{16}$ Zob. np. L. J. Liebreich, Notes on the Greek Version of Symmachus, ,Journal of Biblical Literature" 63 (1944), s. 397-403

${ }^{17}$ Zob. np. S. Jellicoe, The Septuagint and Modern Study, Winona Lake ${ }^{1} 1978,{ }^{2} 1989$, 31993, s. 83-94. 
mogłoskowe i akcenty - a więc musiały już być opracowane i wprowadzone do tego czasu. Dodatkowy argument przynosi najstarszy znany nam kodeks Biblii hebrajskiej - Kodeks Kairski. Datowany na 895 rok zawiera już pełny system samogłosek i akcentów. Tak zbudowany system musiał istnieć i rozwijać się już dużo wcześniej, przynajmniej od 100 lat, stąd owa data 750 po Chrystusie wydaje się być najpóźniejszą możliwą datacją dla rozpoczęcia działalności masoretów. Koniec tego okresu przypada na IX-X wiek, z których posiadamy w pełni opracowane kodeksy Biblii hebrajskiej.

Warto na marginesie dodać, że w okresie działalności masoretów Żydzi byli zaangażowani w długotrwałą walkę ideologiczną. Od I wieku judaizm rabiniczny powiększał zakres swych wpływów. W miarę spisywania Talmudu komentarze rabinów do prawa ustnego stawały się ważniejsze od tekstu Biblii. Zachodziła więc obawa, że przestanie się przykładać wagę do zachowania tekstu Biblii. Tendencji tej sprzeciwili się w VIII stuleciu tzw. karaimi. Chcąc uwypuklić znaczenie osobistego studium Pisma Świętego, odrzucali autorytet i interpretacje rabinów oraz sam Talmud. Jedynym miarodajnym źródłem była dla nich Biblia. W związku z tym wzrosła potrzeba wiernego przekazywania jej tekstu, co nadało jeszcze rozmachu pracy masoretów.

\section{Masora BHS}

Pierwsze dwa wydania Biblii hebrajskiej pod redakcją profesora Rudolfa Kittela (BHK 1905 i 1913) $)^{18}$ opublikowane zostały bez not masoreckich, a jedynie z masorecką punktacją i kantylacją. Oba oparto na Kodeksie z Aleppo (A), który zawsze cieszył się wielki uznaniem Żydów ${ }^{19}$. W trzecim wydaniu Biblii hebrajskiej Kittela (BHK 1937) ${ }^{20}$ zrezygnowano z prezentowania jako podstawy Kodeksu z Aleppo na rzecz Kodeksu

${ }^{18}$ Biblia Hebraica, edidit R. Kittel, Stuttgart ${ }^{1} 1905,{ }^{2} 1913$.

${ }_{19}$ Żydzi do dziś wydają Tanach w oparciu o ten właśnie kodeks, np. The Aleppo Codex, t. 1: The Plates, ed. by M. H. Goshen-Gottstein, Jerusalem 1976; Sefer Yesha yahu, ba-'arikhat M. Goshen-Gotșhtại, Yerushalayim 1995 (Torah, Nevi’im, Ketuvim, mahadurat ha-Universitạh ha-'Ivrit bi-Yerushalayim Bible); JPS Hebrew-English Tanakh. The Traditional Hebrew Text and the New JPS Translation, Philadelphia ${ }^{2} 1999$.

${ }^{20}$ Biblia Hebraica, edidit R. Kittel, textum masoreticum curavit P. Kahle, Stuttgart ${ }^{3} 1937$, editionem septimam auxerunt et emendaverunt A. Alt et O. Eissfeldt, 1951, ${ }^{9} 1954$. 
Leningradzkiego B19a (L), najstarszego najlepiej zachowanego manuskryptu całej Biblii hebrajskiej. Intencją Kittela była prezentacja nie tylko kodeksu L, ale także całej masory - umieszczenie masory małej (Mp) na marginesach bocznych oraz zaopatrzenie jej w noty alfabetycznie ułożonej masory wielkiej (Mm), która miała się ukazać w osobnym dziele. Zamierzenie to zostało zrealizowane dopiero w nowym opracowaniu Biblii hebrajskiej, znanym jako Biblia Hebraica Stuttgartensia (BHS).

Dzieło opracowania masory zarówno małej, jak i wielkiej powierzono profesorowi Gérardowi E. Weilowi. Weil z powodzeniem podjął się dzieła przedstawienia skompletowanej i zintegrowanej wersji masory małej kodeksu L dla BHS. Masora mała została w BHS umieszczona dokładnie tak jak w Kodeksie Leningradzkim. Terminologia i skróty masory zostały ujednolicone, a opuszczenia uzupełnione. Jednak na opracowanie masory wielkiej trzeba było poczekać aż do roku 1971, kiedy to Weil wydał masorę wielką w tomie towarzyszącym BHS ${ }^{21}$. Tom zawiera uszeregowaną listę not masoreckich umieszczonych ponad i pod tekstem kodeksu L (not masory wielkiej). Porządek not ponumerowanych od 1 do 4271 jest podyktowany kolejnością ich pojawiania się w kodeksie. Dzięki umieszczeniu konkordancji każda z nich jest skorelowana z notami masory małej umieszczonej na marginesach bocznych BHS. W ten sposób czytelnik BHS, który ma dostęp do Massorah Gedolah Weila, może się poruszać od tekstu hebrajskiego przez masorę małą (marginalną) do masory wielkiej i z powrotem do tekstu Biblii. Możliwości, jakie otwiera taka lektura, zostaną przedstawione poniżej.

\section{Jak czytać masorę BHS}

Wyraz czy zwrot, do którego odnosi się uwaga masorecka, jest zaznaczony w tekście małym kółeczkiem ponad wyrazem zwanym w angielskim wstępie do BHS circule. Jest to charakterystyczny znak masoretów. Jeśli kółko znajduje się na środku ponad wyrazem, oznacza to, że posiada on notę masorecką na marginesie. Natomiast, gdy kółko znajduje się nad tekstem pomiędzy dwoma wyrazami, oznacza to, że nota marginalna dotyczy całej frazy. Noty marginalne pisane są najczęściej skrótami,

${ }^{21}$ G. Weil, Massorah Gedolah iuxta codicem Leningradensem B 19a, Romae-Stuttgartensiae 1971. 
niewprawny czytelnik potrzebuje zatem słownika owych skrótów, który w BHS znajduje się po prolegomena i słowniku aparatu krytycznego. Jeśli nota na marginesie zawiera więcej niż jedno słowo, są one pisane jedne pod drugim. Porządek not na marginesie od prawej do lewej jest taki sam jak wyrazów w tekście. Niektóre noty marginalne posiadają odnośniki liczbowe, cyfry w indeksie górnym, które odsyłają pod tekst do konkretnego miejsca w masorze wielkiej. Np. gdy przy nocie masory bocznej pojawi się cyfra ${ }^{1}$ (np. ${ }^{1}$ ב), odnosi się ona do noty pod tekstem oznaczonej ${ }^{1}$, gdzie wskazano konkretne miejsce w masorze wielkiej, w którym rozwinięto uwagę z masory bocznej (np. ${ }^{1}$ Mm 192). Każda nota na dole posiada skrót Mm (masora magna, masora wielka) oraz numer, pod którym w Massorah Gedolah Weila znajdziemy owo rozwinięcie. Powyższe oznaczenie Mm 192 odsyła do 192 numeru Massorah Gedolah Weila. Przed ${ }^{1} \mathrm{Mm}$ pojawia się skrót rozdziału, do którego należą kolejne noty, np. skrót Cp 22 (Chapter 22) w oznaczeniach masory dolnej oznacza biblijny rozdział 22 - kolejne noty Mm należą do tego rozdziału.

\section{Praca z masorą}

Aby zrozumieć i dobrze wykorzystać masorę w badaniach tekstu biblijnego, trzeba pamiętać o naczelnym celu, który przyświecał jej twórcom: noty masoreckie pojawiają się tam, gdzie łatwo popełnić jakiś błąd, gdzie formy hebrajskiego tekstu nie są jednoznaczne. Np. gdy jakiś wyraz jest pisany głównie pełną samogłoską (tzw. scriptio plena), a rzadko ułomną, bez mater lectionis (tzw. scriptio defectiva), masora mała to odnotuje, by czasem z przyzwyczajenia nie wstawić i nie czytać tu samogłoski pełnej, która niekiedy zmieni znaczenie wyrazu. Lub gdy jakiś wyraz jest rodzaju żeńskiego, a kilka razy jest potraktowany jak męski (np. przez dodanie męskiego zaimka wskazującego), to masora zaznaczy te wyjątki, gdyż istniało duże ryzyko harmonizacji tych kilku miejsc według zasady ogólnej (rzeczownik żeński). Uwagi masoreckie nie były jednak czymś tylko teoretycznym - notami w miejscach, gdzie mó gł się pojawić błąd. Najczęściej dotyczyły miejsc, gdzie ten błąd faktycznie się pojawiał.

W ten sposób masora chroni tekst oryginalny i pokazuje miejsca szczególne hebrajskiej Biblii. Dlatego gdy w analizowanej przez tłu- 
macza czy egzegetę perykopie tekstu hebrajskiego pojawia się nota masory bocznej - warto zapytać: dlaczego znalazła się tu masorecka nota? Na co wskazuje? Co stara się ochronić? Na co zwrócić uwagę? W pracach i opracowaniach egzegetycznych rzadko zwraca się uwagę na system not masoreckich i zdarza się, że prowadzi to do nieścisłości $\mathrm{w}$ interpretacji biblijnego tekstu.

\section{Qere iketiw. Qere perpetuum}

Masoreci rozwinęli całą gamę technicznych terminów pozwalających ująć cechy tekstu, które chcieli wynotować. Wśród nich na szczególną uwagę zasługują tzw. uwagi q $q^{e} r{ }^{e} k^{e} t i w$, które to słowa są aramejskimi imiesłowami biernymi oznaczającymi odpowiednio: „czytany” (lectum, legendum) i „napisany” (scriptum). Masora używa ich do zaznaczenia poprawek domniemanych lub rzeczywistych błędów, które wkradły się do tekstu spółgłoskowego podczas jego przekazu, a więc tam, gdzie litery sugerują inny wyraz niż był tradycyjnie czytany. Q'e oznacza to, jak dany wyraz powinien być odczytany, a ketiw wskazuje, jakie odczytanie wynika z tekstu spółgłoskowego. Najpopularniejszą w manuskryptach formą oznaczania ketiw (przyjętą dziś także w BHS i BHQ) jest zwokalizowanie go samogłoskami należącymi do q ${ }^{e}$ re oraz umieszczenie kółka nad wyrazem, które odsyła na margines, gdzie wskazano poprawne (poprawione) spółgłoski do odczytania. Ketiw jest zatem reprezentowany przez wyraz spółgłoskowy w tekście, a q $q^{e}$ re przez samogłoski w tekście i wyraz spółgłoskowy na marginesie. Np. w Rt 3, 3 znajdziemy formę

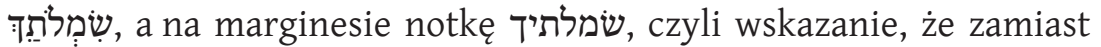

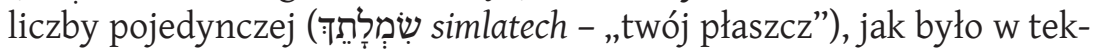
ście spółgłoskowym, winno się odczytać (שָׁמְלת simlotajich - „twoje płaszcze"). Znak ק wskazuje na qe - skrót od קרידי 22 Inne przykłady zob. np. w Rdz 8, 17; Pwt 33, 2; $1 \mathrm{Krl} \mathrm{6,16.} \mathrm{Całkowitą} \mathrm{liczbę} \mathrm{uwag} \mathrm{q} \mathrm{re-ketiw}$ szacuje się na 800-1500. Poprawki qere służą najczęściej jako eufemizm (16 przypadków poprawienia brzydkiego słowa); unormowanie nietypo-

${ }^{22}$ We wczesnych manuskryptach spotykamy różne sposoby oznaczania $q^{e} r e, n p$. w pewnych manuskryptach palestyńskich oznacza się je dwiema kropkami (..) na marginesie linii, gdzie występuje $k^{e} t i w, w$ innych poprzez znak przypominający końcowe inun, a w pewnych nie są zaznaczane. 
wej pisowni plene czy defective; uwspółcześnienie starych form (często $k^{k}$ tiw przedstawia formę bardziej archaiczną) oraz unormowanie form dialektowych; poprawki błędów metatezy (przestawienia), opuszczenia, dodania czy zastąpienia liter i inne.

Jak widzimy, masoreci z szacunku do natchnionego tekstu spółgłoskowego nic w nim nie zmieniali, nie poprawiali nawet oczywistych błędów, a jedynie wynotowywali poprawną według nich formę na marginesie $^{23}$. System ten był bardzo słuszny, gdyż pozwolił zachować tekst spółgłoskowy nienaruszony. Choć większość naniesionych poprawek zasługuje na pełne uznanie i akceptację, z niektórymi można się nie zgadzać. Zdarzają się sytuacje, gdy ketiw jest tak samo dobry lub nawet lepszy od qere (zob. np. Rdz 8, 17 czy 2 Sm 22, 51).

Qere perpetuum to stałe poprawki, których ze względu na dużą częstotliwość występowania nie umieszczano już na marginesie, ale wynotowywano poprzez anomalną wokalizację. Dotyczy popularnych słów, które należy wymawiać inaczej, niż sugeruje to tekst spółgłoskowy. Najważniejszą z tych poprawek jest punktacja tetragramu ${ }^{24}$, do

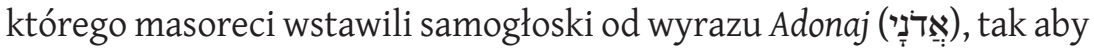
z szacunku do świętego imienia Boga nie wymawiać go, lecz czytać ( $\left.q^{e} r e\right)$ Adonaj - „Pan” (dosł. „moi panowie”).W ten sposób powstało יִ: błędnie odczytane już w średniowieczu jako Jehowa. Formy tej używano także w przedwojennych edycjach Biblii, a dziś gorliwie bronią jej świadkowie Jehowy. Odczytanie to jest błędne z tego powodu, że spółgłoski pochodzą od imienia Bożego, a samogłoski od innego wyrazu. Najbardziej prawdopodobna wymowa tetragramu יהוה brzmiała: Jahwe (יהוהוה (25). Innym

${ }^{23}$ Masoreci nie wprowadzili do tekstu spółgłoskowego żadnych zmian poza kilkunastoma (około 18 w całej Biblii hebrajskiej) poprawkami wyrażeń czy zwrotów niestosowanych. Błędów w tekście nie poprawiali.

${ }^{24}$ Tetragram to pojęcie z języka greckiego (tetragrammaton - dosł. „cztery litery”) oznaczające cztery święte litery imienia Bożego.

${ }^{25}$ Rekonstrukcja dokonana zwłaszcza na podstawie starożytnych transkrypcji tetragramu na inne języki, gdyż ze względu na Boży zakaz wymawiania tetragramu znajomość wymowy tego imienia wymarła. Inne warianty w badaniach historyczno-lingwistycznych tetragramu to m.in. Jaho(h), Jahu, Jabe, Jabaj, Jawo, Jowa - zob. G. J. Thierry, The Pronunciation of the Tetragrammaton, „Oudtestamentische Studiën” 5 (1948), s. 30-42. Zgodnie z tradycją biblijną imię Boże JHWH nie jest wymawiane zarówno w tradycji żydowskiej, jak i chrześcijańskiej. Mówi o tym drugie przykazanie dekalogu. Poprzez tłumaczenie Septuaginty (tu tetragram zastępowano gr. Kyrios - „Pan”) trady- 


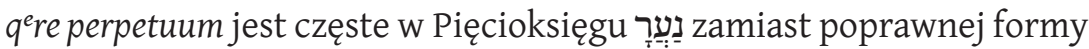
נַעַרָה („dziewczyna”). Jest to po prostu pewna osobliwość ortograficzna, można by powiedzieć zwykły błąd ortograficzny.

\section{Funkcje masory}

Zaczęliśmy mówić, jakie funkcje spełniają uwagi $q^{e} r e-k^{e} t i w$, masora jednak nie ogranicza się tylko do tych poprawek. Możemy mówić o wielu rodzajach uwag stosowanych w masorze. Omówię pokrótce najważniejsze $\mathrm{z}$ nich.

Uwagi o charakterze statystycznym informują, jak często pojawia się dana cecha czy forma w całej Biblii hebrajskiej, w Torze, u Proroków, w Pismach lub w konkretnej księdze. Np. częste marginalne $خ$ oznacza hapax legomenon, formę występującą w Biblii tylko raz; $\dot{j}$ oznacza trzykrotne występowanie, i sześciokrotne itd. (zgodnie z wartością liczbową nadaną kolejnym literom alfabetu hebrajskiego) ${ }^{26}$. Dla

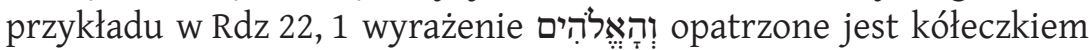
na górze, a na marginesie oznaczeniem ${ }^{1}$ i, które mówi, że wyraz Bóg z rodzajnikiem i spójnikiem 1 występuje w Biblii hebrajskiej dokładnie 7 razy. Cyfra ${ }^{1}$ odsyła do oznaczeń pod tekstem, gdzie pod jedynką widnieje Mm 145. Pod numerem 145 w Massorah Gedolah Weila znajdziemy wyszczególnienie pozostałych sześciu miejsc występowania. Ponieważ masora wielka powstała w czasie, gdy tekst biblijny nie był jeszcze podzielony na rozdziały i wersety (nie można było wskazać sigli biblijnych) ${ }^{27}$, cytuje ona część odpowiedniego fragmentu, gdzie ta sama

cja niewymawiania imienia Bożego przeszła do chrześcijaństwa (Hieronim w Wulgacie konsekwentnie tłumaczy Dominus - „Pan”) i ostatnio została przypomniana przez Benedykta XVI.

${ }^{26} \mathrm{Nad}$ literą musi pojawić się kropka, by miała ona wartość liczbową. System stosowania liter alfabetu hebrajskiego jako oznaczeń cyfrowych został wprowadzony w czasach pobiblijnych. W Biblii stosuje się liczby i cyfry pisane pełnymi nazwami (przymiotnikami ,jeden” i „dwa” oraz rzeczownikami kolektywnymi - pozostałe liczebniki). Zatem próby odczytywania biblijnych zdań i wyrazów jako ciągu liter i doszukiwanie się tu sensu pozostaje spekulacją.

${ }^{27}$ Podziału na rozdziały dokonali chrześcijanie w łacińskiej Wulgacie dopiero w XIII wieku (wprowadzone przez abpa Canterbury S. Langtona). Później Żydzi zaakceptowali ten podział, choć utrzymali jednocześnie masorecki podział Tory. 
forma się pojawia, aby wskazać, gdzie w Biblii można jeszcze znaleźć dany wyraz lub grupę wyrazów ${ }^{28}$.

Uwagi statystyczne mają dziś dla egzegety znaczenie drugorzędne, gdyż jesteśmy w posiadaniu wielu znakomitych biblijnych programów komputerowych, które - pod warunkiem ułożenia odpowiedniego zapytania - znajdą bezbłędnie wszystkie szukane biblijne formy oraz wyliczą ich procentowy udział w poszczególnych księgach.

Uwagi o charakterze jakościowym informują o cechach tekstu bez podawania danych ilościowych. Często towarzyszy im wyraz כ kol (,wszystko”, ,wszystkie”, ,cały”), gdyż podają cechę pojawiająca

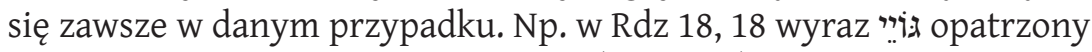
jest kółkiem, a na marginesie notką: 17 כל אוריז מל מ, (,wszystkie w Torze plene", czyli: wszystkie występowania tego wyrazu w Pięcioksięgu są pisane plene). Liczba występowań nie jest podana, ale można spokojnie przyjąć, że wszystkie będą pisane we wskazany sposób. Indeks ${ }^{17}$ wskazuje na dolną notę Mm 152, gdzie można odnaleźć listę miejsc występowania. Te noty pomagają zachować poprawną pisownię także w sytuacjach, gdy jest ona nieregularna bądź wyjątkowa. Jeśli np. słowo jest pisane w pewien sposób 30 razy, a 4 razy w sposób odmienny, istnieje ryzyko pomyłki, pisania tych czterech miejsc w typowy sposób (harmonizacji). Masora nie tylko zaznaczy owe miejsca wyjątkowe, ale często poda wykaz wystąpień regularnych i nieregularnych, dając całościowy obraz wskazanej cechy tekstu.

Poprawki, uzupełnienia i skreślenia.Masora pojawia się często tam, gdzie do spółgłoskowego tekstu hebrajskiego wkradł się błąd. Wtedy ma charakter poprawki zaznaczonej w tekście i na marginesie ( $q^{e}$ re i $\left.k^{e} t i w\right)$, przy q $q^{e}$ re perpetuum - tylko w tekście. Np. w Pięcioksięgu $\mathrm{w}$ tekście hebrajskim pojawia się dość często zaimek osobowy żeński „ona" w takiej formie: הוא (ketiw), który trzeba czytać jako היא (qee - jota zamiast waw). W każdym z tych przypadków nie będzie już masory marginalnej ${ }^{29}$.

${ }^{28}$ Zwróćmy uwagę, że aby te uwagi na marginesach spełniały swe zadanie, kopiści musieli znać na pamięć niemal całą Biblię hebrajską.

${ }^{29}$ Czego zdaje się nie zauważać Hebrajsko-polski Stary Testament - Pięcioksiag. Przekład interlinearny z kodami gramatycznymi, transliteracjąoraz indeksem rdzeni, Warszawa 2003, gdzie w transliteracji pojawia się stały błąd hiw', którego to słowa nie ma w języku hebrajskim. 
Z kolei uzupełnienia pojawiają się tam, gdzie tekst spółgłoskowy domagał się dodatku, i umieszczane są w postaci samogłosek wstawianych w miejsce, gdzie zdaniem masoretów, brakuje słowa. Np. w Rt 3, 17 w tekście masoreckim mamy: .... (,powiedział”), a na marginesie notatkę: אלי... קרי ולא כחי (elaj... qeere welo ketiw), która podpowiada, że

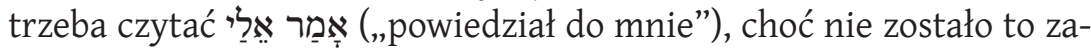
pisane w tekście spółgłoskowym.

Niewielka kropka (romb) umieszczona ponad spółgłoską (jak np.

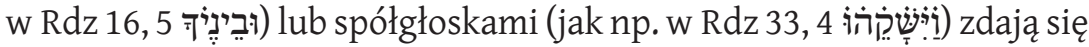
wskazywać na potrzebę usunięcia litery czy liter zaznaczonych w ten sposób ${ }^{30}$. Są to poprawki o charakterze skreślenia. W całym Tanachu jest ich 15: dziesięć w Torze, cztery u Proroków i jedna w Pismach.

Uwagi dotyczące paralel pokazują pewną cechę tekstu i wskazują paralelne (identyczne) oraz podobne miejsca. Należą do nich uwagi o charakterze statystycznym, ale także np. nota ושאר (usze'ar - „, reszta”), która informuje, że wszystkie inne formy zgodnie z podanymi parametrami są jednakowe, lecz różnią się w jakiś sposób od zaznaczonego i wynotowanego słowa.

U wagi mnemotechniczne, nie tak częste, mają na celu to, aby czytelnik, tłumacz czy kopista zapamiętał pewne ważne cechy tekstu, np. gdzie występuje paralelny fragment albo jak wymawia się daną serię wyrazów, czy różny porządek słów itp. Np. lista mieszkańców Kanaanu jest podana w Biblii kilkanaście razy. Tam, gdzie porządek wymieniania kolejnych mieszkańców jest różny od przyjętej normy, a więc istnieje ryzyko, że także w przepisywaniu czy tłumaczeniu zastosuje się typowy porządek zamiast tego szczególnego, zaznaczone jest to w Mp, aby temu zapobiec.

Uwagi o charakterze aparatu krytycznego. Niektóre noty powołują się na znane autorytety w zakresie przekazu tradycji biblijnej. Jest ich niewiele. Np. do Ps 31, 12 czy 1 Krn 12, 7 znajdziemy notę ken lewen Aszer („tak według ben Aszera”). Uczony żydowski powołuje się na autorytet odczytywania Mosze ben Aszera. Często przy tej okazji wynotowuje się alternatywne odczytanie ben

${ }^{30}$ Trwa dyskusja na temat ostatecznego znaczenia owych punków, a domysły rabinów świadczą, że już nawet oni nie potrafili ich jednoznacznie odszyfrować. Według niektórych kropki te wskazują na wątpliwość tradycji. 
Neftalego, sławnego adwersarza ben Aszera. Czasem inna tradycja zaznaczona jest po prostu przez מהלפ (יו) (תא) (תלון (,jest inna opinia"). Jest to więc funkcja zbliżona do tej, jaką spełnia dziś aparat krytyczny BHS, przytaczając warianty innych kodeksów. Także niektóre poprawki $q^{e} r e-k^{e} t i w$ zdają się wskazywać na alternatywne odczytanie pochodzące z innych manuskryptów.

Rolę poprawek lub pewnych innych wskazówek pełnią też n i et ypowe kształty i formy liter, np. litery podniesione do góry (tzw. zawieszone), litery powiększone, zmniejszone czy napisane w nietypowy sposób. Nie są one jednak identyczne we wszystkich manuskryptach i w dużej części tych przypadków nie jesteśmy dziś w stanie doszukać się właściwego sensu owych zabiegów masoretów.

*

Podsumowując, jedną z poważnych barier w studiowaniu masory Biblii hebrajskiej jest brak literatury wprowadzającej w jej tematykę, zwłaszcza na gruncie języka polskiego. W biblijnych opracowaniach polskojęzycznych nie znajdziemy żadnego szerszego wprowadzenia w studiowanie not masoreckich. Od kiedy system not masoreckich jest pieczołowicie zamieszczany w BHS czy BHQ, tym pilniejszą wydaje się potrzeba gruntowego wprowadzenia do tematyki masory. Niech ten artykuł będzie zwiastunem takiego opracowania.

\section{Bibliografia}

Prolegomena, [w:] Biblia Hebraica Stuttgartensia, quae antea cooperantibus A. Alt, O. Eißfeldt, P. Kahle, ediderat R. Kittel, editio funditus renovata adjuvantibus H. Bardtke [et al.], cooperantibus H. P. Rüger et J. Ziegler, ediderunt K. Elliger et W. Rudolph, textum Masoreticum curavit H. P. Rüger, masoram elaboravit G. E. Weil, Stuttgart 1997; L. H. Brockington, The Hebrew Text of the Old Testament, London 1973; P. H. Kelly, D. S. Mynatt, T. G. Crawford, The Masorah of Biblia Hebraica Stuttgartensia. Introduction and Annotated Glossary, Grand Rapids-Cambridge 1998; C. McCarthy, What's New in BHQ? Reflections on BHQ Deuteronomy, „Proceedings of the Irish Biblical Association” 30 (2007), s. 54-69; S. Morag, The Vocalisation System od Arabic, hebrew and Aramaic, The Hague 1962; D. S. Mynatt, The Sub Loco Notes in the Torah of Biblia Hebraica Stuttgartensia, N. Richland Hills 1994; J. D. Price, The syntax of masoretic accents in the Hebrew Bible, Lewiston 1990; T. Römer, J. D. Macchi, Guide de la Bible hébraïque. La critique textuelle dans la Biblia Hebraica Stuttgartensia (BHS), Genève 1994, ${ }^{22006 ; ~ J . ~ A . ~ S a n d e r s, ~ T h e ~ H e b r e w ~ U n i v e r s i t y ~ a n d ~ B i b l i a ~}$ Hebraica Quinta, „Journal of Biblical Literature” 118 (1999), s. 518-526; W. R. Scott, 
A Simplified Guide to BHS. Critical Apparatus, Masora, Accents, Unusual Letters and Other Markings, Berkeley-California 1987; L. Stachowiak, Nowe wydanie krytyczne Biblii hebrajskiej, „Ruch Biblijny i Liturgiczny” 23 (1970), s. 232-234; R. Wonnenberger, Leitfaden zur Biblia Hebraica Stuttgartensia, Göttingen 1984; I. Yeivin, Introduction to the Tiberian Masora, Atlanta 1985 (Masoretic Studies, 5).

Kraków MARCIN MAJEWSKI

\section{Słowa kluczowe}

Masora, znaki masoreckie, Biblia hebrajska

\section{Summary}

\section{Masorah of the Hebrew Bible - introduction into the problem}

Masorah (oral and written tradition of transmitting the Bible text) is an important library of information about Sacred Scripture on the stage of its formation. It provides informations without which it is difficult and sometimes impossible to read or interpret correctly the biblical text. One of the barriers involved studying the Masorah of the Hebrew Bible is the lack od introductory literature on the subject, especially on the field of polish language. Here we can not find any comprehensive and useful study for the Masorah, including exercises and examples how to read and take advantage of Masorah. Since the system of Masoretic notes is very carefully printed in Biblia Hebraica Stuttgartensia, and even more in Biblia Hebraica Quinta, we require such a study of masoretic notes' system in Polish biblical studies. This article is an announcement of such an elaboration.

\section{Keywords}

Masorah, Masoretic notes, Hebrew Bible 